\title{
Impact of a Growing Population on Natural Resources: The Challenge for Environmental Management
}

\section{David Pimentel}

\section{$X$. Huang}

\section{A. Cordova \\ M. Pimentel}

\section{Introduction}

A HEA LTHY and prudently managed environment is a major benefit to humans and other species. All life on earth obtains its food and other necessities from this environment. Indeed, humans and all living organisms rely on the basic resources found in the earth's environment for their very survival. Paramount among these resources are fertile land, fresh water, energy, and biodiversity. Already the human population is utilizing more than 50 percent of the solar energy captured by all the plant biomass on earth each year (Pimentel et al., 1996a). Humans and other organisms obtain all their food and fiber from this photosynthetic activity.

Currently the world population is about 6 billion and is projected to reach 10 billion by 2040 , based on the present growth rate of 1.5 percent per year (PRB, 1995). This excessive number should signal a call for action concerning resource use and management. Erosion of farmland, overuse of both surface and groundwater, dwindling supplies of finite fossil fuels, and escalating extinction of plant and animal species imperil the ability of the earth's resources to meet the needs of such enormous numbers of humans.

The food situation worldwide is becoming critical. At present, more than 2 billion humans are malnourished and experience unhealthy living conditions (FAO, 1992a,b; Neisheim, 1993; McMichael, 1993; Maberly, 1994; Bouis, 1995). The number of humans who also are diseased is the largest number ever, and about 40,000 children die each day from disease and malnutrition (Kutzner, 1991; Tribe, 1994). 
The many problems that are now evident emphasize the urgent need to reassess the status of environmental resources. Based on the evidence, definitive plans must be developed to improve environmental management now and for the future. Of major importance is the limiting and slow reduction of human numbers to better balance the carrying capacity of the earth's natural resources.

\section{Populations and Consumption of Resources}

Human behavior demonstrates a strong will to survive, to reproduce, and to achieve some level of prosperity and quality of life. However, individuals as well as societies differ in their views of what they consider a satisfactory lifestyle. Contrasting some aspects of life in the United States, China, and the rest of the world reveals many disparities in lifestyles, which most often are functions of the quantity of natural resources available per person. Furthermore, most of these basic resources (land, water, energy, and biota) are not unlimited in their supplies and many are finite. As human populations continue to expand, prosperity and the quality of life can be expected to decline because resources must be divided among more people (UNFPA, 1991; RS and NAS, 1992).

Recent decades have witnessed a great expansion of populations throughout the world. The U.S. population doubled from 130 million to more than 260 million during the past 60 years (NGS, 1995) and is projected to double again to 520 million during the next 60 years based on the current rate of growth of 1.1 percent per year (USBC, 1994). In contrast, China currently has a population of 1.2 billion, and despite the governmental policy of permitting only one child per couple, it too is growing at a rate of 1.1 percent (PRB, 1995). China's desirable population is 650 million or about one-half of the current population level (Qu and Li, 1992). The number of people in India is nearly 1 billion living on about one-third the land of either the United States or China; however, its rate of increase is 1.9 percent, which is equivalent to a doubling time of 37 years (PRB, 1995). Together, China and India have more than one-third of the total world population. Although these populations are projected to double in 60 and 37 years respectively, it is doubtful that either population will double because their declining resources will limit such growth. Because most nations will have similar 
constraints in land, water, energy, and biological resources relative to population density, it is unlikely that the world population will double in the next 50-100 years despite the current projection (PRB, 1995).

In addition to limitations on resource availability, high consumption rates also limit resources. For example, each American consumes about 23 times more goods and services than the average citizen of a developing country. One average American consumes about 53 times more goods and services than a Chinese citizen (PRB, 1995). Achieving the U.S. standard of living and that of most developed nations is unrealistic for the developing nations, based both on projections of future resource availability and population growth. The excessive consumption levels characteristic of Americans also have led to dependence on the importation of natural resources, as reflected in the fact that the United States has the highest debt of any nation in the world (USBC, 1994). With declining resources throughout the world, this ability to import foreign resources no doubt will be curtailed.

Since the 1850s, Americans have relied increasingly on diverse energy sources rather than human power to produce their food and forest products. These relatively cheap and abundant supplies of fossil fuel have been substituted for human and draft animal energy. Fossilbased fertilizers and pesticides, as well as fossil-run machinery, have enabled U.S. farmers to diminish the level of human energy they must expend to farm the land. However, at present Chinese farmers use more fertilizer and pesticides per hectare than American farmers (Wen and Pimentel, 1992). They also depend on about $1200 \mathrm{hrs} /$ ha per year of human labor for grain production, compared with only $10 \mathrm{hrs} / \mathrm{ha}$ per year for the U.S. farmer (Wen and Pimentel, 1984; Wen and Pimentel, 1992).

Industry, transportation, home heating, and food production account for most of the fossil energy consumed in the United States (DOE, 1991; DOE, 1995a). In China most fossil energy is used by industry, but a substantial amount, approximately 25 percent, is used for food production (Kinzelbach, 1983; Smil, 1984; Wen and Pimentel, 1992). Per capita use of fossil energy in the United States is 8740 liters of oil equivalents per year or more than 12 times that of China (Table 1). Furthermore, U.S. per capita energy consumption is nearly seven times the world average, a clear demonstration of over-consumption. 
Thus far, the relative affluence enjoyed by most Americans has been possible because of abundant per capita supplies of fertile cropland, water, and fossil energy. As the U.S. population continues to expand, resource shortages similar to those now being experienced by China and many other nations will become common (Tables 1 and 2). In fact, indications are that the average standard of living in the United States began to decline during the last decade (Fuchs and Reklis, 1992) and is projected to continue to decline if the U.S. population doubles during the next 60 years (Pimentel and Pimentel, 1996). Already measurable shortages of fertile land, water, and fossil energy exist in many regions of the world (Worldwatch Institute, 1992; WRI, 1994). This should serve as a warning to all people.

Status of World Environmental Resources

The quantity and quality of arable land, water, energy, and biodiversity balanced against human population numbers determine the current and future status of the very environmental resources that support human life.

\section{Land Resources}

More than 99 percent of human food comes from the terrestrial environment, and the remaining small percentage comes from the oceans, lakes, and other aquatic ecosystems (Pimentel and Pimentel, 1996). Worldwide, food and fiber crops are grown on 12 percent of the earths total land area (Buringh, 1989). Another 24 percent of the land is used as pasture to graze livestock that provide meat and milk products; forests cover an additional 31 percent (Buringh, 1989). The small percentage of forest and grassland set aside as protected national parks to conserve biological diversity amounts to only 3.2 percent of the total terrestrial ecosystem (Reid and Miller, 1989). Most of the remaining portion of land area (34 percent), is unsuitable for crops, pasture, and forests because it is too cold, dry, steep, stony, or wet, or because the soil is too infertile or shallow to support plant growth (Table 3) (Buringh, 1989).

To provide a diverse nutritious diet of plant and animal products, about 0.5 ha of cropland per capita is needed (Lal, 1989). At present, 
the United States has slightly more than this amount. In China, only 0.08 ha of cropland is available to feed the people; this is rapidly declining both because of continuing population growth and rapid land degradation (Leach, 1995). The world cropland average is only 0.27 ha available per capita, or roughly one-half the needed amount (Table 1). This shortage of productive cropland is, in part, the cause of the food shortages and poverty that many humans are experiencing today (Leach, 1995).

Currently, a total of $1481 \mathrm{~kg}$ of agricultural products are produced annually to feed each American, while the Chinese food supply averages only $476 \mathrm{~kg} / \mathrm{capita} / \mathrm{yr}$. Note that the world average value is 614 $\mathrm{kg} /$ capita/yr. Based on available data, each person in China eats essentially a vegetarian diet. By all measurements, the Chinese have reached the carrying capacity of their agricultural system. Their reliance on large inputs of fossil based fertilizers and other inputs to compensate for severely eroded soils foreshadows problems in the future (Wen and Pimentel, 1992). The Chinese are also planning for huge inputs of grains (Brown, 1995).

Escalating land degradation threatens most crop and pasture land throughout the world (Lal and Pierce, 1991; Pimentel et al, 1995). The major types of degradation include rainfall and wind erosion, and the salinization and water-logging of irrigated soils (Kendall and Pimentel, 1994). Worldwide, more than 10 million hectares of productive arable land are severely degraded and abandoned each year (Pimentel et al., 1995). Moreover, each year an additional 5 million hectares of new land must be put into production to feed the nearly 100 million humans added yearly to the world population. Most of the total of 15 million hectares needed for both replacement and expansion is coming from the world's forests. The urgent need for more agricultural land accounts for more than 60 percent of the deforestation now occurring worldwide (Myers, 1990).

Soil erosion by wind and water is the single most serious cause of soil loss and degradation. Erosion rates are greater than ever before in history, averaging about $30 \mathrm{t} / \mathrm{ha} / \mathrm{yr}$ worldwide (Pimentel and Hall, 1989; WRI, 1991; Pimentel et al., 1995). Soil erosion on cropland ranges from about $13 \mathrm{t} / \mathrm{ha} / \mathrm{yr}$ in the United States to $40 \mathrm{t} / \mathrm{ha} / \mathrm{yr}$ in China (USDA,1994; Wen, 1993; McLaughlin, 1993). In Africa during the past 30 years, the rate of soil loss has increased 20 times (Tolba, 1989). Wind 
erosion is so serious in China that Chinese soil can be detected in the Hawaiian atmosphere when planting starts in China (Parrington et al.,1983). Similarly in 1992, soil eroded from Africa was detected in Florida and Brazil (Simons, 1992). Worldwide, soil erosion is about 30 t/ha/yr (Pimentel, 1993).

The current erosion rate throughout the world is of particular concern because of the slow pace of topsoil formation; it takes approximately 5()o years for $2.5 \mathrm{~cm}$ (1 inch) of topsoil to form under agricultural conditions (OTA, 1982; Elwell, 1985; Troeh et al., 1991; Pimentel et al., 1995). Thus, topsoil is being lost 13 to 40 times faster than it is being replaced.

Erosion adversely affects crop productivity by reducing water availability, water holding capacity of the soil, soil nutrients, soil organic matter, and soil depth-all factors that depress plant growth. Estimates are that agricultural land degradation can be expected to depress world food production between 15 and 30 percent during the next 25-year period unless new production strategies are used to curtail this loss (Buringh, 1989).

Unfortunately, the arable land currently used for crop production already includes considerable marginal land which is highly susceptible to erosion. When soil degradation occurs, crop production is depressed and the requirement for fossil energy inputs in the form of fertilizers, pesticides, and irrigation is increased to offset the losses (OTA, 1982; Follett and Stewart, 1985; Pimentel, 1993; Pimentel et al., 1995).

\section{Water Resources}

The present and future availability of adequate supplies of fresh water is frequently taken for granted. Natural collectors of water such as rivers and lakes vary in distribution throughout the world and frequently are shared within and between countries. All surface water supplies, especially those in arid regions, are diminished by evaporation. For instance, reservoir water experiences an average yearly loss of about 24 percent (Meyers, 1962).

All vegetation requires and transpires massive amounts of water during the growing season. For example, a corn crop that produces about $7500 \mathrm{~kg} / \mathrm{ha}$ of grain will take up and transpire about 5 million liters/ha of water during the growing season (Leyton, 1983). To supply 
this much water to the crop, not only must 8 million liters ( $800 \mathrm{~mm}$ ) of rain fall per hectare, but a significant portion must fall during the growing season (Pimentel et al., 1996b).

The greatest threat to maintaining fresh water supplies is the overdraft of surface and groundwater resources used to supply the needs of the rapidly growing human population and of the agriculture which provides its food. Agricultural production "consumes" more fresh water than any other human activity (Falkenmark, 1989). About 87 percent of the fresh water that is pumped worldwide is "consumed" (nonrecoverable) by agriculture (Postel, 1989), while in the United States this figure is about 85 percent (NAS, 1989). All people require nearly three liters of water per day, including the water in milk and other foods, but need a minimum of ninety liters per day for cooking, washing, and other domestic needs (Brewster, 1987). Each American uses about 400 liters per day for domestic needs (USBC, 1994).

About eighty nations in the world already are experiencing significant water shortages (Gleick, 1993). For instance, more than 300 cities in China are short of water and the problem is intensifying (WRI, 1994). Furthermore, in arid regions where yearly rainfall is scarce, the future of agricultural production is grim, especially as their populations grow.

Providing an ever-increasing amount of water requires the use of all sources of water, both surface and groundwater. For example, by the time the Colorado River reaches Mexico it has almost disappeared before finally trickling into the Sea of Cortes. Excessive removal of its water, mainly by the states of California, Arizona, and Colorado, is the cause (Sheridan, 1983).

Surface water in rivers and lakes and groundwater each supply the freshwater resources in the world (Wolman, 1986; Falkenmark, 1989). Groundwater resources are renewed at various rates, but usually at the extremely slow rate of ().1-0.3 percent per year (UNEP, 1991; Covich, 1993). Because of their slow recharge rate, groundwater resources must be carefully managed to prevent overdraft. Yet humans are not effectively conserving groundwater resources, and overdrafting is now a serious problem worldwide. For example, in Tamil Nadu, India groundwater levels declined 25-30 m during the 1970 s because of excessive, but needed, pumping for irrigation (Postel, 1984; UNFPA, 1991). In Beijing, China's groundwater table is diminishing at a rate of 
about $1 \mathrm{~m}$ per year while in Tianjin, China it drops $4.4 \mathrm{~m}$ per year (Postel, 1984). In the United States, aquifer overdraft averages 25 percent higher than the replacement rate (USWRC, 1979). But in the vast U.S. Ogallala aquifer, annual overdraft is 130-160 percent above replacement (Beaumont, 1985). If this continues, this vital aquifer is expected to become nonproductive in about forty years (Soule and Piper, 1992).

High consumption of surface and groundwater resources is beginning to limit the option of irrigating arid regions. Furthermore, per capita irrigation area is also declining because of salinization and waterlogging, both deleterious effects of continual irrigation (Postel, 1989).

Another major threat to maintaining ample fresh water resources is pollution caused by people and industries. Considerable water pollution is documented in the United States (USBC, 1994), but it is more serious in countries that have regulations which are not enforced. In some Latin American countries, untreated urban sewage is dumped into rivers and lakes (WRI, 1991), resulting in a serious health problem due to fecal coliform bacterial counts that can be much higher than 1 million-the maximum acceptable level for U.S. drinking water. Pesticides, fertilizers, and soil sediments also pollute water resources as they accompany eroded soil, while industries dump untreated toxic chemicals into rivers and lakes (WRI, 1991). Pollution by sewage and disease organisms-as well as by the 100,000 different chemicals used worldwide-make water unsuitable not only for human drinking but for application to crops (Nash, 1993).

\section{Energy Resources}

Some form of energy is used by humans to provide them with their many needs and desires. Over time, humans relied on their own energy, animal power, wind and water power, and gradually turned to wood, coal, gas, and oil for fuel and power. Worldwide about 381 quads from all energy sources are used per year. Currently, energy expenditure is directly related to the rapid growth in the world population and the associated environmental degradation imposed by human activity (Table 4). 
Although worldwide about 50 percent of all solar energy captured by photosynthesis is used by humans, this is inadequate to meet their needs for food and forest products (Pimentel, 1989; Pimentel et al., 1996a). To make up the shortfall, about 321 quads (1015 BTU or $337 \mathrm{X}$ 1018 Joules) of fossil energy are utilized worldwide each year (UNEP, 1985; IEA, 1991). Of this, 81 quads are consumed just in the United States (DOE, 1995a,b). American consumption of fossil fuel is about three times the 28 quads of solar energy harvested as crop and forest products each year. Thus, the U.S. population consumes 40 percent more fossil energy than all the solar energy captured by U.S. vegetation (Pimentel and Pimentel, 1996).

In agriculture and forestry, fossil fuels are used to run machinery, pump water, and supply fertilizers and pesticides. Fossil energy is used to fuel a wide array of other human activities including industrial production; fuel for automobiles, trains and trucks; highway construction; heating and cooling of buildings; and the packaging of goods, to mention a few.

Fossil energy is used to feed an increasing number of humans as well as to improve the quality of life in many basic ways, such as protecting humans from numerous diseases. For example, delivering clean water and treating sewage helps reduce a wide array of disease organisms that are transmitted in polluted water. Despite this use of fossil energy, about 90 percent of all human diseases are water borne (Pimentel et al., 1996b).

Developed nations annually consume about 80 percent of the fossil energy worldwide while developing nations, which have about 75 percent of the world population, consume only 20 percent (UNEP, 1985; DOE, 1991). The United States annually consumes about 25 percent (81 quads) of the world's fossil energy output (Pimentel et al., 1993). Fossil energy use in different U.S. economic sectors has increased 20-1000-fold in the past three to four decades, attesting to Americans' heavy reliance on this finite energy resource to support their affluent lifestyles (Pimentel and Hall, 1989; Pimentel and Pimentel, 1996).

Several developing nations that have high rates of population growth are increasing the use of fossil fuels to augment their agricultural production of food and fiber. In China, as mentioned, there has been a 100-fold increase in the use of fossil energy in agriculture 
since 1955 (Wen and Pimentel, 1992). This increase has been mainly for fertilizers, pesticides, and irrigation.

Overall projections of the availability of fossil energy resources are discouraging. A recent report published by the U.S. Department of Energy (DOE, 1991) based on current oil drilling data indicates that the estimated amount of national oil reserves has plummeted. This means that instead of the 35-year supply of U.S. oil reserves that was projected about eight years ago, the current known and discoverable potential oil and natural gas reserves are now limited to a 20-year supply based on present rates of pumping (DOE, 1990; Lawson, 1991; BP, 1994). Given that the United States is now importing more than half its oil, it is obvious that a serious fossil fuel shortage already exists (Gibbons and Blair, 1991).

The world supply of oil is greater than that of the United States and is projected to last from 30-50 years at current pumping rates (Matare, 1989; BP, 1994). Both in the United States and the world, the natural gas supply is adequate for 20-35 years and coal for about 100 years (Matare, 1989; BP, 1994; Bartlett and Ristinen, 1995). However, these estimates are based on current consumption rates and current population numbers. If all people in the world enjoyed a standard of living and energy consumption rate similar to that of the U.S. average, and the world population continued to grow at a rate of 1.5 percent, the world's fossil fuel reserves would last a mere 15 years.

At present, transportation represents 40 percent and electricity represents about 34 percent of total U.S. energy consumption (nuclear energy contributes 18 percent of the electric needs) (USBC, 1994). Nuclear energy production of electricity has some advantages over fossil fuels because its production requires less land than coal fired plants, causes fewer human injuries and deaths, and its use does not contribute to acid rain and global warming (Holdren, 1991; Meeks and Drummond, 1991). However, there are several limitations to the expansion of the use of nuclear fission and, eventually, fusion as future energy sources. First, uranium resources needed for both are limited worldwide and are expected to last about 100 years, without nuclear breeder reactors (fusion) (Hafele, 1991). Second, the risks of disposing radioactive wastes and lack of public acceptance for storage of wastes may curtail the widespread use of both fission and fusion energy 
(Hafele, 1991). Fusion technology will require a great many years of research for development before it will be ready for use (Matare, 1989).

Both nuclear fission and fusion technologies produce enormous amounts of waste heat, which is a serious environmental pollutant (Bartlett, 1989; Bartlett, 1995). For example, it has been estimated that if the number of nuclear power plants in the United States were increased from the current 108 to 1500 , the temperature of U.S. aquatic ecosystems would increase about 10\% C (H. Kendall, Department of Physics, MIT, personal communication, 1992). Such heat pollution would seriously damage the environment and cause a major loss of biological diversity in aquatic and terrestrial systems. Also, it would alter existing climate patterns which could adversely affect agricultural and forestry production. Thus, it would be impossible to supply all U.S. energy needs at the present rate of consumption with fusion, even if we assume that it is developed (Bartlett, 1995).

\section{Biological Resources}

In addition to land, water resources, and crop and livestock species, humans depend on the presence and functioning of approximately 10 million other species that exist in agroecosystems and nature (Pimentel et al., 1992). Humans have no technologies that can substitute for the service provided by wild biota. In the United States there are approximately 500,000 species of plants, animals, and microbes that carry out many essential activities for humans including pollination of crop and wild plants; recycling manure and other organic wastes; degrading chemical pollutants; and purifying water and soil (Pimentel et al., 1992).

Clearly humans depend on these organisms as well as their livestock and crop species. For example, honey bees and wild bees play an essential role in pollinating about 840 billion worth of U.S. crops annually in addition to pollinating natural plant species (Pimentel et al., 1996a). Estimates are that honey bees and wild bees in New York State on a bright, sunny day in July pollinate 6 trillion blossoms (Pimentel, 1994). Humans have no technology to substitute for this natural service supplied by wild biota.

In addition, a diverse group of species serve as a vital reservoir of genetic material for future development of agriculture and forestry, as 
well as for medicines needed to fight disease. Yet, with each passing day, an estimated 150 species are being eliminated because of increasing human numbers and human activities, including deforestation, soil and water pollution, pesticides, as well as urbanization and industrialization (Reid and Miller, 1989).

Resources and Human Diseases

Diseases are associated with diminishing quality of water, air, and soil resources and many rob humans of their health and eventually their livelihood. Profound differences exist between the causes of death in developed and developing regions of the world. Communicable, maternal, and/or perinatal diseases account for 40 percent of the deaths in developing regions but only 5 percent in developed regions (WHO, 1994). While there is a complex of factors that are responsible, inadequate food and contaminated water and soil are the major contributors to disease and human health problems.

Diseases and malnutrition are interrelated and, as might be expected, parasitic infections and malnutrition coexist where there is poverty and poor sanitation (Shetty and Shetty, 1993). Poverty and lack of sanitation can be as severe in certain sectors of urban areas as they are in rural areas; several studies point to the inequalities even in different parts of cities (Atkinson, 1993). Urban environments, especially those without proper sanitation, are becoming an increasing concern in terms of their potential for the spread of disease as they become overcrowded (Science, 1995). The high density of people in urban environments provides no protection from pollution caused by accumulation of city wastes in water, air, and soil and creates favorable conditions for the rapid spread of infectious diseases that can easily reach epidemic proportions (WHO, 1992).

About 90 percent of the diseases occurring in developing countries result from a lack of sanitary water (WHO, 1992). Worldwide, about 4 billion cases of disease are contracted from water and approximately 49 million deaths are caused by all diseases from water and other sources each year (WHO, 1992). Shistosomiasis, which is common throughout the tropics, is an example of a parasitic disease associated with contaminated water, while hookworms are present in contaminated moist soils in the tropics. 
Hookworms infect nearly 1 billion people. Malaria, spread by mosquitoes, infects 800 million worldwide (Walsch and Warren, 1979) while tuberculosis is estimated to infect about 1 billion humans (Cohen, 1996). In many areas where sanitation is inadequate, polyparasitism is a common occurrence and further compounds health problems (Keusch and Migasena, 1982).

Intestinal parasites reduce the intake of nutrients in various ways, such as the loss of nutrients through diarrhea or dysentery, impairment of nutrient absorption, alteration of appetite and food intake, and blood loss (Shetty and Shetty, 1993). Hookworms, for instance, can remove up to $30 \mathrm{cc}$ of blood from a person in a day, leaving the person weak and susceptible to other diseases (Hotez and Pritchard, 1995). We estimate that between 5 and 20 percent of an individual's daily food intake is used to offset illnesses and the stress of disease, thereby diminishing the nutritional status of the infected person (Pimentel et al., 1996c).

At first glance, human health seems unrelated to resources, but it soon becomes apparent that it is affected not only by quantities of resources (e.g., food and water) but how resources are handled and kept pure. As human populations increase in size, the risks to their health and productivity grow, especially where sanitation is inadequate.

\section{Constraints in Managing Resources}

The prime resources land, water, energy, and biological resources function interdependently and each can be manipulated, to some extent, to make up for a partial shortage in one or more of the others. For example, to bring desert land into agricultural production, it can be irrigated. However, this is a viable strategy only if groundwater or surface water is available, if sufficient fossil energy is available to pump and move the water, and if the soil is suitable for irrigation and fertile enough to support crop growth.

The fertility of nutrient poor soil can be improved by large inputs of fossil-based fertilizers. Yet, the practice increases dependency on finite fossil fuels. A more basic problem, however, is that about 3,000 years are needed for the natural reformation of topsoil to the $15 \mathrm{~mm}$ depth necessary for satisfactory crop production. Even with fertilizer use, soil erosion remains a critical problem for current agricultural production. Crops can be grown hydroponically, but the cost in terms of energy and 
dollars is approximately 10 times that of conventional agriculture (Schwarz, 1995).

Although some new technologies and environmental management practices are improving the use of resources, there are practical limits to their role. For example, fish production in oceans and other aquatic ecosystems has not increased with the availability of larger, faster ships and larger nets (Mitchell and Cleveland, 1993). In fact, fish production reached a peak in 1988 and is slowly declining because of poor management, overfishing, and pollution. As a result the cod fisheries on the east coast of Canada, for example, have been overfished, and now there are 80,000 fishermen on welfare and desperate for work (W. Rees, University of British Columbia, personal communication, 1996).

Forest production and regrowth have not increased with the availability and use of large, efficient chain saws. To the contrary, forests everywhere in the world are on the decline (WRI, 1994).

Furthermore, no existing technology can double the flow of the Colorado River, or enhance other surface and groundwater resources. However, better environmental management and conservation of water can help make more efficient use of the freshwater that is available. For example, drip irrigation in agriculture can reduce the use of water by nearly 50 percent (Pimentel et al., 1996b).

\section{Improving Resource Management}

Because the availability of all essential resources is fast diminishing, the options for substitution are also diminishing. This emphasizes the urgency of conservation and the development of alternative strategies. Certainly soil erosion requires a major effort if agricultural production is to be sustainable for the future. Numerous farm practices that conserve soil fertility are known but not used as much as in previous decades. These include use of cover crops, grass strips, ridge planting, as well as crop rotations (Pimentel et al., 1995). Preventing soil erosion conserves soil nutrients, increases water retention of soil, and improves overall soil quality.

To lessen dependency on commercial fertilizers, the underutilization and waste of livestock manures should be rectified (Pimentel, 1996a; Pimentel et al., 1995). Proper use of manures-which contain significant amounts of nitrogen, phosphorus, and potassium- 
will enhance soil nutrients and concurrently diminish the use of fossil fuel resources.

Pests destroy growing crops and thereby reduce food and fiber supply; yet, despite the yearly use of 2.5 million tons of pesticides and other controls worldwide, about 40 percent of all potential crop production is lost to pests (insects, diseases, and weeds) (Pimentel, 1996b). In the United States, about 0.5 tons of pesticides are applied and pests destroy about 37 percent of all potential crop production. Since 1945, the use of synthetic pesticides in the United States has grown 33-fold, yet crop losses to pests continue to increase (Pimentel et al., 1991). For example, despite a 1000-fold increase in the use of insecticides on corn, corn losses to insects have risen nearly 4 -fold (Pimentel et al., 1991). Furthermore, residues of pesticides pollute the environment, destroying beneficial species and creating human health problems (Pimentel and Greiner, 1996).

Although large quantities of pesticides are being applied, much is wasted through the use of inappropriate methods of application or used when they are not really needed (Pimentel, 1996b). In addition, changes in agricultural technologies, especially in intensive agriculture, have increased pest populations. For some major crops like corn, the practice of crop rotations has been abandoned; nearly one-half of U.S. corn land is used to grow corn continuously as a monoculture. These changes have caused an increase in the number of corn pests and require that increased amounts of pesticides be used to protect the crop (Pimentel et al., 1991). Adopting sustainable and environmentally sound agricultural technologies, including a return to crop rotations, would stem soil erosion; conserve fertile land; reduce water requirements for irrigation; decrease pesticide and fertilizer use; and save fossil fuel, soil, and water resources (Pimentel et al., 1995).

There is no way to increase the rainfall that supplies our surface and groundwater stores. However, more effective use of water is possible, for example by using drip irrigation instead of sprinkle irrigation. This situation can reduce the amount of water needed by 50 percent (Pimentel et al., 1996b).

Reduced water consumption by individuals and associated water conservation policies are paramount for sustainability. If this is not done, crop production will be diminished, especially in arid regions. 
Also, competition will intensify within regions and between countries when water is scarce.

The use of ocean water by desalinization is not a viable solution for agriculture because desalinization is both energy and dollar costly. For example, to irrigate one hectare of corn with desalinized water would cost $\$ 14,000$ while all other inputs, like fertilizers, cost only 8500 (Pimentel et al., 1996b). This figure does not include the costs of moving large amounts of water from the sea to agricultural fields.

With the imminent decline in fossil fuels, a transition will have to be made from fossil energy to renewable energy sources. High priority should be given to researching ways to convert solar energy into usable energy and to the development of new sources such as nuclear fusion. Although many solar technologies have been investigated, at present most are in limited use. The most promising include solar thermal receivers, photovoltaics, solar ponds, windpower, hydropower, and biomass (Pimentel et al., 1994).

By using the available renewable energy technologies, an estimated 40 quads of energy could be produced in the United States while using about 20 percent of the available land area (Pimentel et al., 1994). This development will affect agriculture and forestry to some extent, but not seriously, provided U.S. population numbers are limited to about 200 million (Pimentel et al., 1994). This suggests that the United States must establish a population policy that is related to the resources available and the standard of living it desires (Pimentel et al., 1994).

As mentioned, both large and small diverse species carryout vital functions in the environment, while plants remove carbon dioxide from the air and add oxygen. There are no substitute technologies for most of these environmental and ecological services.

No one knows which species or how many species can be exterminated before the functioning of the ecosystem is threatened and/or made inoperable. Scientists have reported that if sufficient natural biological diversity is to be maintained to ensure a quality environment, then about one-third of the terrestrial ecosystem should be preserved as natural vegetation (Odum, 1971). This biomass is considered essential to provide food, shelter, and protection for these valuable species and ensure the preservation of adequate biodiversity for future generations (Heywood, 1995; Pimentel et al., 1996a). 
David Pimental, X. Huang, A. Cordova, M. Pimentel

Conclusion

Improved environmental management and the redistribution of food and wealth would help relieve the problems of the more than 2 billion malnourished people and 1.5 billion people currently living in poverty in the world (Neisheim, 1993; Speth, 1996). The mean income per family in the United States is about $\$ 37,000$ per year and many suggest there is overconsumption and waste of goods and resources. If food and wealth were redistributed, malnourishment could be eliminated and the mean income for all families worldwide would be about $\$ 6,700$. Is this a suitable standard of living for a family? For some families in the world this $\$ 6,700$ would be an improvement, but American and European families reduced to this level would not feel that this was a suitable standard of living.

If, however, a population of 1 to 2 billion were achieved in the world, a relatively high standard of living would be possible for everyone and an ample and diverse food supply would be available. This level of prosperity would be possible only if land, water, energy, and biological resources are not degraded further and sound environmental management practices were adopted. However, even with sound environmental practices, if the world population increases to 10 billion and has better food distribution, many more humans than at present will be malnourished, hungry, and living in poverty.

Fertile land, a prime resource, not only is deteriorating through constant use and erosion, but the land that is available must be divided among increasing numbers of humans. A similar trend is occurring with water supplies. As usage increases, surface and groundwater sources are being used faster than they can be replenished by rainfall. Increased competition among individuals, agriculture, and industry-as well as between regions and countries-tends to exacerbate water problems.

At current levels of use most oil, natural gas, and coal reserves will be used up within the next century as actual rates of consumption are driven higher by population growth and rising consumer expectations. Because fossil energy resources are finite, new renewable energy will be needed. Additionally, as human activities expand throughout the earth s ecosystem, plant and animal species are rapidly diminishing both in numbers and diversity. When lost, their benefits and services will no longer be available to society and the environment at large. 
Based on their evaluations of available world natural resources, scientists of the Royal Society and the U.S. National Academy of Sciences have issued a joint statement reinforcing the concern about the growing imbalance between the world's population and the resources that support human lives (RS and NAS, 1992). Thus far, individuals and government leaders appear unaware, unwilling, or unable to deal with the growing imbalances between human population numbers and the energy and environmental resources that support all life. The interdependencies existing among the availability of life supporting resources, individual standards of living, the quality of the environment, environmental resource management, and population density are neither acknowledged nor understood. Humans have a disappointing record in effective environmental management to protect their essential resources and the environment from over exploitation in the face of rapidly growing populations (Pimentel et al., 1989).

Historically, decisions are based on isolated crises and usually are made only when catastrophes strike. Such decisions have been ad hoc, designed to protect and/or promote a particular resource or aspect of human well being instead of examining the problem in a holistic manner. Based on past experience, we are concerned that urgent decisions concerning the human carrying capacity of the world will not be made until the situation becomes intolerable, or worse still, irreversible (Pimentel et al., 1994; Pimentel and Giampietro, 1994; Pimentel et al., 1996a).

With a population control policy that respects basic individual rights, sound resource use policies, and the support of science and technology to enhance energy supplies and protect the integrity of the environment, an optimum population can be achieved. If all people work together, fundamental obligations to future generations can be achieved. Then individuals will be free from poverty and starvation and live in an environment that will sustain human life with dignity.

\section{Bibliography}

Agrostat. (1992) Agrostat Data Base. FAO 1992 Data Base.

Arkinson, S.J. (1993) Urban health in the Third World: A guide to the

literature. Environment and Urbanization 5: 146-152.

Bartlett, A.A. (1989) Fusion and the future. Physics and Society, 18 (3): 11. 
Bartlett, A.A. (1995) Fusion: An Illusion of a practical source of energy? Clearing House Bulletin. 4(1): 1-3, 7.

Bartlett, A.A., and R.A. Ristinen. (1995) Natural gas and transportation. Physics and Society 24 (4): 9-10.

Beaumont, P. (1985) Irrigated agriculture and groundwater mining on the high plains of Texas, USA. Environ. Cons., 12, $11 \mathrm{pp}$.

Bennett, G. M. (1995) China Facts and Figures Annual Handbook. Florida: Academic International Press.

Bouis, H.E. (1995) Breeding for nutrition. Journal of the Federation of American Scientists 48(4): 1, 8-16.

BP. (1994) British Petroleum Statistical Review of World Energy. London: British Petroleum Corporate Communications Services.

Brewster, J.A. (1987) World Resource 1987. A Report by the International Institute for Environment and Development and the World Resources Institute. New York: Basic Books, Inc.

Brown, L.R. (1995) Who Will Feed China? New York: W. W. Norton.

Buringh, P. (1989) Availability of agricultural land for crop and livestock production. Pages 68-83 in Food and Natural Resources, D. Pimentel and C.W. Hall (eds.). San Diego: Academic Press.

Cohen, J.E. (1996) How Many People Can the Earth Support? New York: Rockefeller University.

Covich, A.P. (1993) Water and ecosystems. Pages 40-55 in Water in Crisis, P.H. Gleick (ed.). New York: Oxford University Press.

DOE. (1990) Annual Energy Outlook. Washington, DC: U.S. Department of Energy.

DOE. (1991) Annual Energy Outlook with Projections to 2010. Washington, DC: U.S. Department of Energy, Energy Information Administration.

DOE. (1993) Annual Energy Review. Washington, DC: EIA. USDOE.

DOE. (1995a) Annual Energy Outlook with Projections to 2010. Washington, DC: EIA. USDOE.

DOE. (1995b) International Energy Annual 1993. Washington, DC: EIA. USDOE.

Elwell, H.A. (1985) An assessment of soil erosion in Zimbabwe. Zimbabwe Sci. News, 19, 27-31.

Falkenmark, M. (1989) Water scarcity and food production. Pages 164-91 in Food and Natural Resources, D. Pimentel and C.W. Hall (eds.) San Diego, CA: Academic Press.

FAO. (1992a) Food and Nutrition: Creating a Well-Fed World. Rome: Food and Agriculture Organization of the United Nations. 
FAO. (1992b) Nutrition: The Global Challenge. Roma: FAO Sponsored International Conference on Nutrition.

Follett, R.F. and B. A. Stewart. (1985) Soil Erosion and Crop Productivity. Madison, WI: American Society of Agronomy, Crop Science Society of America.

Fuchs, V.R. and D. M. Reklis (1992) America's children: Economic perspectives and policy options. Science 255: 41-46.

Gibbons, J.H. and P. D. Blair. (1991) U.S. energy transition: On getting from here to there. Am. Inst. of Physics, Jul, 21-30.

Gleick, P.H. (1993) Water in Crisis. New York: Oxford University Press.

Hafele, W. (1991) Energy from nuclear power. Scientific American, September, 137-144.

Heywood, V.H. (1995) Global Biodiversity Assessment. United Nations Environment Programme. Cambridge: Cambridge University Press.

Holdren, J.P. (1991) Energy in transition. Pages 119-130 in Energy for Palent Eart, J. Peil (ed.) New York: W.H. Freeman Col.

Hotez, P.J. and D.T. Pritchard. (1995) Hookworm infection. Sci. Amer. 272 (6): 68-75.

IEA. (1991) Energy Statistics of OECD Countries. Paris International Energy Agency.

Kendall, H.W., and D. Pimentel. (1994) Constraints on the expansion of the global food supply. Ambio 23: 198-205.

Keausch, G. T. and P. Migasena. (1982) Biological implications of polyparasitim. Review of Infectious Diseases 4: 880-882.

Kinzelbach, W.K. (1983) China: Energy and environment. Environmental Management, 7 303-310.

Kutzner, P.L. (1991) World Hunger. A Reference Handbook. Santa Barabara, CA: ABC-Clio.

Lal, R. (1989) Land degradation and its impact on food and other resources. Pages 85-140 in Food and Natural Resources, D. Pimentel (ed.) San Diego: Academic Press.

Lal, R. and F.J. Pierce. (1991) Soil Management for Sustainability. Ankeny, IA: Soil and Water Conservation and Soil Sci. Soc. Of Amer.

Lawson, R.L. (1991) The US should increase its use of coal. Pages 41-45 in Energy Alternatives, C.P. Cozic and Polesetksky (eds). San Diego: Greenhaven Press.

Leach, G. (1995) Global Land and Food in the 21 $1^{\text {st }}$ Century. Stockholm: International Institute for Environmental Technology and Management. 
Leyton, L. (1983) Crop water use: principles and some considerations for agroforestry. Pages 379-400 in Plant Research and Agroforestry, P.A. Huxley (ed.) Nairobi, Kenya: International Council for Research in Agroforestry.

Maberly, G.F. (1994) Iodine deficiency disorders: contemporary scientific issues. Journal of Nutrition 124 (8 suppl.): 1473s-1478s.

Matare, H.F. (1989) Energy: Fact and Future. Boca Raton, FL: CRC Press.

McLaughlin, L. (1993) Soil erosion and conservation in Northwestern China. Pages 87-108 in World Soil Erosion and Conservation, D. Pimentel (ed.) Cambridge: Cambridge University Press.

McMichael, A.J. (1993) Planetary Overload: Global Environmental Change and the Health of the Human Species. Cambridge: Cambridge University Press.

Meeks, F. and J. Drummond. (1991) Nuclear power can be environmentally safe. Pages 46-52 in Energy Alternatives, C.P. Cozic and M. Polesetsky (eds.) San Diego, CA: Greenhaven Press.

Meyers, J.S. (1962) Evaporation from 17 Western States. Washington, DC: Geological Survey Professional Paper 272-D.

Mitchell, C., and C.J. Cleveland. (1993) Resource scarcity, every use and environmental impact: a case study of the New Bedford, Massachusetts, USA fisheries. Environmental Management 17: 305-317.

Myers, N. (1990) Mass extinctions: What can the past tell us about the present and future? Global and Planetary Change, 2: 82.

NAS. (1989) Alternative Agriculture. Washington, DC: National Academy of Sciences.

Nash, L. (1993) Water quality and health. In Water in Crisis: A Guide to the World's Fresh Water Resources, P. Gleick (ed.). Oxford: Oxford University Press.

Nesheim, M. C. (1993) Human nutrition needs and parasitic infections. Pages s7-s18 in Parasitology: Human Nutrition and Parasitic Infection, D.W.T. Crompton (ed.). Cambridge: Cambridge University Press.

NGS. (1995) Water: A Story of Hope. Washington, DC: National Geographic Society.

Odum, E.P. (1971) Fundamentals of Ecology. Philadelphia: W.B. Saunders Co.

OTA. (1982) Impacts of Technology on U.S. Cropland and Rangeland Productivity. Washington, DC: Office of Technology, U.S. Congress.

Parrington, J.R. Zoller, W.H., and N.K. Aras. (1983) Asian dust: seasonal transport to the Hawaiian Islands. Science, 246: 195-197. 
Pimentel, D. (1989) Ecological systems, natural resources, and food supplies. Pages 1-29 in Food and Natural Resources, D. Pimentel and C. W. Halls (eds.). San Diego: Academic Press.

Pimentel, D. (ed). (1993) World Soil Erosion and Conservation. Cambridge: Cambridge University Press.

Pimentel, D. (1994) Insects and related arthropods. In The encyclopedia of the Environment. Boston: Houghton Mifflin Co.

Pimentel, D. (1996a) Conservation of fertilizers and livestock manure: pollution prevention. Manuscript.

Pimentel, D. (ed.) (1996b) Techniques for Reducing Pesticides: Environmental and Economic Benefits. Chichester, U.K.L John Wiley \& Sons. In press.

Pimentel, D. and M. Giampietro. (1994) Implications of the Limited Potential of Technology to Increase the Carrying Capacity of Our Planet. Human Ecology Review Summer/Autumn, 1: 248-251.

Pimentel, D., and A. Greiner. (1996) Assessment of environmental and economic impacts of pesticide use. In Techniques for Reducing Pesticides: Environmental and Economic Benefits, D. Pimentel (ed.) Chicester, U.K.: John Wiley \& Sons. In press.

Pimentel, D., and M. Pimentel. (1996) Food, Energy and Society. Niwot, CO: University Press of Colorado.

Pimentel, D., Armstrong, L.E., Flass, C.A., Hopf, F.W., Landy, R.B., and M.H. Pimentel. (1989) Interdependence of food and natural resources. Pages 31-48 in Food and Natural Resources, D. Pimentel and C.W. Halls (eds.). San Diego: Academic Press.

Pimentel, D., McLaughlin, L., Zepp, A., Lakitan, B., Kraus, T., Kleinman, P., Vancini, F., Roach, W.J., Graap, E., Keeton, W.S., and G. Selig. (1991) Environmental and economic impacts of reducing US agricultural pesticide use. Pages 679-718 in Handbook of Pest Management in Agriculture, D. Pimentel (ed.). Boca Raton, FL: CRC Press.

Pimentel, D., Stachow, U., Takacs, D.A., Brubaker, H.W., Dumas, A.R., Meaney, J.J., O’Neil, J., Onsi, D.E., and D.B. Corzilius. (1992) Conserving biological diversity in agricultural/forestry systems. BioScience, 42: 354362.

Pimentel, D., McLaughlin, L., Zepp, A., Lakitan, B., Kraus, T., Kleinman, P., Vancini, F., Roach, W.J., Graap, E., Keeton, W.S., and G. Selig. (1993) Environmental and economic effects of reducing pesticide use in agriculture. Agriculture, Ecosystems and Environment 46 (1-4): 273-288. 
Pimentel, D., Harman, R., Pacenza, M., Pecarsky, J., and M. Pimentel. (1994) Natural resources and an optimum human population. Population and Environment 15: 347-369.

Pimentel, D., Harvey, C., Resosudarmo, P., Sinclair, K. Kurz, D., McNair, M., Crist, S., Sphpritz, L., Fitton, L., Saffouri, R., and R. Blair. (1995) Environmental and economic costs of soil erosion and conservation benefits. Science 267: 1117-1123.

Pimentel, D., McCullum, C., Huang, R., Wilson, C., Dwen, P., Flack, J., Tran, Q., Saltman, T., and B. Cliff. (1996a) Environmental and economic benefits of biodiversity. Manuscript.

Pimentel, D., Houser, J., Preiss, E., White, O., Fang, H., Mesnick, L., Barsky, T., Tariche, S., Schreck, J., and S. Alpert. (1996b) Water resources: Agriculture, the environment and society. BioScience. In press.

Pimentel, D., Huang, X., Cordova, A., and M. Pimentel. (1996c) Impact of population growth on food supplies and environment. Manuscript to be submitted to Population Review and Development.

Postel, S. (1984) Water: Rethinking Management in an Age of Scarcity. Worldwatch paper no. 62. Washington, DC: Worldwatch Institute.

Postel, S. (1989) Water for Agriculture: Facing the Limits. Washington, DC: Worldwatch Institute.

PRB. (1995) World Population Data Sheet. Washington, DC: Population Reference Bureau.

PRC. (1994) Year Book of 1994 of the People's Republic of China. Beijing: PRC Yearbook, Ltd.

Qu, G. and J. Li. (1992) Population and Environment in China. Beijing: China Environmental Science Press (Chinese.)

Reid, W.V. and K. R. Miller. (1989) Keeping Options Alive: The Scientific Basis for Conserving Biodiversity. Washington, DC: World Resources Institute.

RS and NAS. (1992) The Royal Society and the National Academy of Sciences on Population Growth and Sustainability. Population and Development Review 18 (2): 375-378.

Schwarz, M. (1995) Soilless Culture Management. Advanced Series in Agricultural Sciences 24. Berlin: Springer-Verlag.

Science. (1995) Cities as disease vectors. Science 270: 1125.

Sheridan, D. (1983) The Colorado: An engineering wonder without enough water. Smithsonian, February, 45-54.

Shetty, P.S., and N. Shetty. (1993) Parasitic infection and chronic energy deficiency in adults. Supplement to Parasitology 107: S159-S167. 
Simons, M. (1992) Winds toss Africa's soil, feeding lands far away. New York Times, October 29: A1, A16.

Smil, B. (1984) The Bad Earth, Environmental Degradation in China. Armonk, NY: M. E. Sharpe, Inc.

Soule, J.G., and D. Piper. (1992) Farming in Nature's Image: An Ecological Approach to Agriculture. Washington, DC: Island Press.

Speth, J.G. (1996) The US and the UN: Back to the Future. 19 February 1996. Charleston, SC: World Affairs Forum.

SSBPRC. (1990) The Yearbook of Energy Statistics of China in 1989. Beijing: State Statistical Bureau of PRC, Chinese Statistical Press.

Tolba, M.K. (1989) Our biological heritage under siege. BioScience, 39: 725728.

Tribe, D. (1994) Feeding and Greening the World. Oxon, U.K.: CAB International.

Troeh, F.R., Hobbs, J.A., and R.L. Donahue. (1991) Soil and Water Conservation for Productivity and Environmental Production. Englewood Cliffs, N.J.: Prentice-Hall.

UNEP. (1985) Energy Supply Demand in Rural Areas in Developing Countries. Report of the Executive Director. Nairobi: United Nations Environment Programme.

UNEP. (1991) Freshwater Pollution. New York: United Nations Population Fund.

UNFPA. (1991) Population and the Environment: The Challenges Ahead. New York: United Nations Population Fund.

USBC. (1994) Statistical Abstract of the United States 1991. Washington, DC: U.S. Bureau of the Census, U.S. Government Printing Office.

USDA. (1993) Agricultural Statistics. Washington, DC: U.S. Department of Agriculture, Government Printing Office.

USDA. (1994) Summary Report 1992 National Resources Inventory. Washington, DC: Soil Conservation Service, USDA.

USWRC. (1979) The Nation's Water Resources 1975-20oo. Second National Water Assessment. Washington, DC: U.S. Water Resources Council.

Walsch, J.A. and K.S. Warren. (1979) Selective primary health care: An interim strategy for disease control in developing countries. New England Journal of Medicine 301: 967-974.

Wen, D. (1993) Soil erosion and conservation in China. Page 63-86 in World Soil Erosion and Conservation, D. Pimentel (ed.). Cambridge: University of Cambridge Press. 
Wen, D. and D. Pimentel. (1984) Energy inputs in agricultural systems of China. Agriculture, Ecosystems and Environment 11: 29-35.

Wen, D., and D. Pimentel. (1992) Ecological resource management to achieve a productive, sustainable agricultural system in northeast China. Agriculture, Ecosystems and Environment 41: 215-230.

WHO. (1992) Our Planet, Our Health: Report of the WHO Commission on Health and Environment. Geneva: World Health Organization.

WHO. (1994) Global Comparative Assessments in the Health Sector: Disease Burden, Expenditures, and Intervention Packages. Geneva: World Health Organization.

Wolman, M.G. (1986) Consensus, conclusions, and major issues in water resources. Page 117-126 in Managing Water Resources, J. Cairns and R. Patrick (eds.). New York: Praeger.

Worldwatch Institute. (1992) State of the World. Washington, DC: Worldwatch Institute.

WRI. (1991) World Resources 1990-91. New York: Oxford University Press.

WRI (1994) World Resources 1994-95. Washington, DC: World Resources Institute. 


\section{TABLE 1.}

Resources used per capita per year in the United States, China, and the world to supply basic needs

\begin{tabular}{llll}
\hline Resources & USA & China & World \\
\hline Land & & & \\
$\quad$ Cropland (ha) & $0.71^{\mathrm{a}}$ & $0.08^{\mathrm{c}}$ & $0.27^{\mathrm{e}}$ \\
Pasture (ha) & $0.91^{\mathrm{a}}$ & $0.33^{\mathrm{c}}$ & $0.57^{\mathrm{e}}$ \\
Forest (ha) & $1.00^{\mathrm{a}}$ & $0.11^{\mathrm{c}}$ & $0.75^{\mathrm{e}}$ \\
$\quad$ Total (ha) & 3.49 & $0.5^{2}$ & 1.59 \\
\hline Water (liters X 10 & $5.1^{\mathrm{b}}$ & $0.46^{\mathrm{c}}$ & $0.64^{\mathrm{c}}$ \\
\hline Fossil Fuel & & & \\
$\quad$ Oil equivalents (liters) & $8740^{\mathrm{b}}$ & $700^{\mathrm{d}}$ & $1500^{\mathrm{f}}$ \\
\hline Forest Products (kg) & $1091^{\mathrm{b}}$ & $40^{\mathrm{c}}$ & $70^{\mathrm{g}}$
\end{tabular}

a) USDA (1993); b) USBC (1994); c) ORC (1994); Bennett, (1995), d) SSBPRC (1990);

e) Buringh (1989); g) UNEP (1985).

\section{TABLE 2.}

Foods and feed grains supplied per capita $(\mathrm{kg})$ per year in the United States, China, and the rest of the world

\begin{tabular}{lrrr}
\hline Food/Feed & USA $^{\mathbf{1}}$ & China $^{\mathbf{2}}$ & World $^{\mathbf{2}}$ \\
\hline Food grain & $\mathbf{1 0 0}$ & $\mathbf{2 2 8}$ & $\mathbf{1 7 1}$ \\
\hline Vegetables & 105 & 86 & 69 \\
\hline Fruit & 125 & 26 & 57 \\
\hline Meat and fish & 137 & 40 & 45 \\
\hline Dairy products & 247 & 7 & 70 \\
\hline Eggs & 14 & 7 & 6 \\
\hline Fats and oils & 28 & 5 & $\mathbf{1 1}$ \\
\hline Sugars and sweeteners & 62 & 7 & 448 \\
\hline Total food & 818 & 406 & 448 \\
\hline Feed grains & 663 & 70 & 166 \\
\hline \multicolumn{1}{c}{ Grand Total } & 1,481 & 476 & 614 \\
\hline Kcal/person/day & 3,644 & 2,734 & 2,698 \\
\hline .
\end{tabular}

1. USDA(1993).

2.Agrostat Data Base (1992). 
David Pimental, X. Huang, A. Cordova, M. Pimentel

\section{TABLE 3.}

\section{Land Area (Million ha) Uses in Major Regions of the World (WRI, 1991)}

\begin{tabular}{lrrrrr}
\hline Region & Total Area & Cropland & Pasture & Forest & Other $^{1}$ \\
\hline Africa & 2,965 & 184 & 792 & 688 & 1,301 \\
\hline N. America & 2,139 & 274 & 368 & 684 & 813 \\
\hline S. America & 1,753 & 140 & 468 & 905 & 240 \\
\hline Asia & 2,679 & 450 & 678 & 541 & 1,010 \\
\hline Europe & 473 & 140 & 84 & 157 & 92 \\
\hline Total & 10,009 & 1,188 & 2,390 & 2,975 & 3,456 \\
\hline & $100 \%$ & $12 \%$ & $24 \%$ & $30 \%$ & $34 \%$ \\
\hline
\end{tabular}

1. Land that is either too dry, too steep, or too cold to use for agriculture and forestry.

\section{TABLE 4.}

Fossil and solar energy use in the USA and world (Quads)

\begin{tabular}{lrr}
\hline & USA & World \\
\hline Total Consumption & $87.27^{\mathrm{a}}$ & 381.13 \\
& & \\
\hline Petroleum & $33.71^{\mathrm{a}}$ & $136.17^{\mathrm{b}}$ \\
\hline Natural gas & $20.81^{\mathrm{a}}$ & $75.15^{\mathrm{b}}$ \\
\hline Coal & $19.43^{\mathrm{a}}$ & $87.60^{\mathrm{b}}$ \\
\hline Nuclear power & $6.52^{\mathrm{a}}$ & $22.10^{\mathrm{b}}$ \\
\hline Biomass & $6.80^{\mathrm{a}}$ & $28.50^{\mathrm{d}}$ \\
\hline Hydroelectric power & $3.00^{\mathrm{c}}$ & $23.81^{\mathrm{b}}$ \\
\hline Geothermal and wind power & $0.30^{\mathrm{c}}$ & $0.80^{\mathrm{b}}$ \\
\hline Biofuels (ethanol) & $3.40^{\mathrm{c}}$ & $7.00^{\mathrm{c}}$ \\
\hline a DOE, 1995a. & & \\
b DOE, 1995b. & & \\
c DOE, 1993. & & \\
d Pimentel et al., 1994. & & \\
e Pimentel and Pimentel, 1996. & &
\end{tabular}

